\title{
IDENTIFIKASI Salmonella sp. Dan Staphylococcus aureus Serta HITUNG JUMLAH TOTAL BAKTERI PADA MARGARIN
}

\author{
Fines Dwi Martanda \\ Prodi D4 Analis Kesehatan, Fakultas Ilmu Kesehatan, UMAHA \\ e-mail: $\underline{\text { finesdwim@gmail.com }}$
}

\begin{abstract}
Margarine is a product of emulsion, both semisolid and liquid made from vegetable fats. The composition of margarine includes fats, water, vitamins $\mathrm{A}$ and vitamin $\mathrm{E}$ as well as other ingredients. At SNI 7388:2009 on the maximum limit of microbial contamination there are some bacteria that are often found in foodstuffs margarine including Salmonella sp. and Staphylococcus aureus. Salmonella sp. bacteria can lead to deman enteric, diarrhea, nausea, stomach cramps. Staphylococcus aureus bacteria are the most frequently used agents to cause skin sepsis, enteric infections, septic and pneumonia. The purpose of research is to know the contamination of Salmonella sp. and Staphylococcus aureus as well as ALT bacteria in margarine. The method used is laboratory experiments. From the results of the identification of 10 samples of Salmonella sp. and Staphylococcus aureus bacteria. As well as the result ALT bacteria meet the quality requirements of margarine.
\end{abstract}

Keywords: margarine, SNI, Salmonella sp., Staphylococcus aureus, ALT

\section{Pendahuluan}

Margarin adalah produk lemak setengah padat yang merupakan emulsi air di dalam lemak yang stabilitasnya meningkat dengan penambahan emulsifier. Margarin mengandung lemak, air dan bahan lainnya meliputi lesitin, cita rasa, aroma, garam, pewarna, vitamin A dan vitamin E (Hasibuan, 2009) . Margarin yang baik adalah margarin yang berbentuk padat dalam suhu ruang namun memiliki daya oles yang baik serta mampu meleleh dalam suhu tubuh, sehingga salah satu parameter penting yang diperhatikan dalam pembuatan margarin adalah sifat pelelehannya (Hasibuan and Hardika, 2015).

Pada awalnya margarin dibuat dengan menggunakan lemak hewani kemudian beralih ke lemak nabati non tropis seperti minyak kedelai, jagung, atau bunga matahari terhidrogenasi agar teksturnya semi padat. Margarin yang mengandung minyak terhidrogenasi mengandung sejumlah asam lemak trans yang berbahaya bagi kesehatan. Meski demikian, proses hidrogenasi masih dapat digunakan namun terbentuknya asam lemak trans harus diminimalisir dengan cara hidrogenasi total atau penuh atau sempurna (Berger and Aini, 2005). Penggunaan lemak alternatif yang tidak mengandung asam lemak trans sangat diperlukan dalam proses pembuatan margarin. Fraksi minyak sawit (palm oil, palm stearin dan palm olein) dan fraksi minyak inti sawit (palm kernel oil, palm kernel olein dan palm kernel stearin) merupakan jenis lemak yang sangat baik digunakan sebagai bahan baku margarin (Hasibuan, 2009). Pembuatan margarin dilakukan dengan cara membuat emulsi antara fase minyak dan fase air yang dikristalkan dengan proses teksturisasi. Ciri khas dari produk margarin adalah warna kekuningan berasal dari zat pewarna baik alami maupun sintetik yang ditambahkan ke dalam formula. Zat pewarna alami yang umum digunakan 
adalah konsentrat karoten (Hasibuan and Hardika, 2015).

Kontaminasi yang terjadi pada makanan dan minuman dapat menyebabkan berubahnya makanan tersebut menjadi media bagi suatu penyakit. Penyakit yang ditimbulkan oleh makanan yang terkontaminasi disebut penyakit bawaan makanan (food born disease). Menurut (PerMenKes, 2011) penyakit bawaan pada makanan disebabkan oleh virus, bakteri, amoeba atau protozoa, parasit, dan penyebab bukan kuman. Salah satu mikroba patogen yang menyebabkan keracunan makanan adalah Salmonella sp. penyakit yang ditimbulkan oleh bakteri ini disebut Salmonellosis.

Salmonella adalah penyebab utama dari penyakit yang disebarkan melalui makanan (food born disease). Pada umumnya, serotipe Salmonella menyebabkan penyakit pada organ pencernaan. Penyakit yang disebabkan oleh Salmonella disebut Salmonellosis. Salmonellosis adalah istilah yang menunjukkan adanya infeksi bakteri oleh bakteri Salmonella sp. Ciri-ciri orang yang mengalami salmonellosis adalah diare, mual muntah, kram perut dan demam pada waktu 8-72 jam setelah memakan makanan yang terkontaminasi oleh Salmonella (Jawetz, Melnick and Adelberg, 2017).

Staphylococcus aureus merupakan jenis bakteri yang memproduksi enterotoksin dan menyebabkan pangan tercemar sehingga dapat mengakibatkan keracunan pada manusia. Bakteri ini dapat diisolasi dari bahan-bahan klinik, carriers, pangan dan lingkungan. Secara klinis, Staphylococcus merupakan genus yang paling penting dari family micrococcaceae. Genus ini dibagi menjadi dua kelompok besar yaitu aureus dan non aureus. Staphylococcus aureus dikenal sebagai penyebab infeksi jaringan lunak seperti toxic shock syndrome (TSS) dan scalded skin syndrome (SSS), yang dapat diketahui dari spesies Staphylococcus yang memberikan hasil positif pada tes koagulase beberapa strein mampu menghasilkan protein toksin yang sangat stabil terhadap panas yang dapat menimbulkan penyakit pada manusia (BSN, 2009). Infeksi akibat perkembangbiakan organisme ini merupakan masalah yang serius di rumah sakit dan fasilitas layanan kesehatan lain. Perkembangbiakan dalam jaringan dapat menimbulkan manifestasi, misalnya rasa panas, sepsis kulit, infeksi pasca operatif, infeksi enterik, septikemia, endokarditis osteomyelitis, dan pneumonia. Gejala klinis untuk infeksi ini relatif lama, biasanya sampai beberapa hari. Penyakit gastroenteritis (enterokolitis atau keracunan makanan) disebabkan oleh enterotoksin stafilokokus yang tahan panas dan ditandai dengan muntah berat, begitu pula dengan diare, kram perut, demam, ketidak seimbangan elektrolit, dan hilangnya cairan tubuh (Widyastuti and Palupi, 2011).

Berdasarkan latar belakang di atas, peneliti melakukan penelitian tentang "Identifikasi Salmonella sp. Dan Staphylococcus aureus Serta Hitung Jumlah Total Bakteri Pada Margarin curah Yang Dijual Di Daerah Sidoarjo".

\section{Metodologi Penelitian \\ Pengumpulan Sampel}

Pada penelitian ini sampel yang digunakan berupa 10 margarin curah yang diambil di wilayah Sukodono, Sidoarjo, Jawa Timur.

\section{Media, Reagen, dan Peralatan}

Media pertumbuhan dan reagen yang digunakan meliputi Nutrient Agar, Buffer phosphate, Selenite broth, $\mathrm{NaCl}$ broth, Mac Conkay, SSA, BAP, KIA, NAS, MSA, glukosa, laktosa, maltosa, sukrosa, Indol, MR/VP, Urea, Lysin, Simon citrate, $\mathrm{H}_{2} \mathrm{O}_{2} 3 \%$, plasma citrat, kovac's, $\mathrm{KOH} 40 \%, \alpha$ naphtol, satu set pengecatan gram yang meliputi pz, carbol gentian violet, air, lugol, alcohol $70 \%$, air fuchsin.

Peralatan yang digunakan meliputi beaker glass, gelas ukur, spatula, Erlenmeyer, neraca analitik, hot plate, pipet skala, karet, 
koran, kapas, bunsen, autoclave, plate, tabung reaksi, pipet tetes, object glass, ose jarum, ose diameter, filler, mikroskop, rak pengecatan, korek, gelas mutiara.

\section{Identifikasi Salmonella sp. Pada Margarin}

Sebanyak $10 \mathrm{~g}$ sampel margarin dimasukkan kedalam media selenit F-broth dan diinkubasi pada $37^{\circ} \mathrm{C}$ selama 24 jam. Kultur pada selenite F-broth ditanam pada media MCA dan SSA kemudian diinkubasi $37^{\circ} \mathrm{C}$ selama 24 jam. Selanjutnya pada koloni yang tumbuh pada SSA ditanam pada media biokia reaksi dan diinkubasi pada $37^{\circ} \mathrm{C}$ selama 24 jam (Ekawati and Yusmiati, 2018).

\section{Identifikasi Staphylococcus aureus Pada Margarin}

Sebanyak 10 g sampel margarin dimasukkan kedalam media $\mathrm{NaCl}$ broth, daan diinkubasi pada $37^{\circ} \mathrm{C}$ selama 24 jam. Kultur pada $\mathrm{NaCl}$ broth ditanam pada media BAP dan MSA, diinkubasi pada $37^{\circ} \mathrm{C}$ selama 24 jam. Koloni tersangka yang tumbuh pada BAP dan MSA dibuat preparat dan cat Gram. Jika didapatkan kokus bergerombol Gram positif, selanjutnya ditanam pada media Loefller serum, Nutrient Agar, dan Mannitol, kemudian diinkubasi pada $37^{\circ} \mathrm{C}$ selama 24 jam. Diamati dan ditata pertumbuhan bakteri pada mediamedia tersebut. Langkah selanjutnya dilakukan uji katalase, oksidase dan koagulase (Ekawati, Pradana and Darmanto, 2019).

\section{Hasil dan Pembahasan Hasil}

Hasil penelitian yang dilakukan pada bulan Februari 2019 di Laboratorium Mikrobiologi Universitas Ma'arif Hasyim Latif (UMAHA) disajikan pada Tabel 4.1 dan tabel 4.2
Tabel 4.1 Hasil Hitung Jumlah Total Bakteri

\begin{tabular}{|c|c|c|c|c|c|}
\hline \multirow{2}{*}{$\begin{array}{c}\text { Kode } \\
\text { Sampel }\end{array}$} & \multicolumn{3}{|c|}{ Angka Lempeng } & \multirow{2}{*}{ Total } & \multirow{2}{*}{$\begin{array}{c}\text { ALT } \\
\text { (cfu/gr) }\end{array}$} \\
\cline { 2 - 5 } & $10^{-1}$ & $10^{-2}$ & $10^{-3}$ & & \\
\hline $\mathrm{M}_{1}$ & 0 & 0 & 0 & 0 & 0 \\
\hline $\mathrm{M}_{2}$ & 0 & 0 & 0 & 0 & 0 \\
\hline $\mathrm{M}_{3}$ & 0 & 0 & 0 & 0 & 0 \\
\hline $\mathrm{M}_{4}$ & 0 & 0 & 0 & 0 & 0 \\
\hline $\mathrm{M}_{5}$ & 0 & 0 & 0 & 0 & 0 \\
\hline $\mathrm{M}_{6}$ & 3 & 10 & 0 & 65 & $6.5 \times 10^{-1}$ \\
\hline $\mathrm{M}_{7}$ & 2 & 0 & 0 & 20 & $2 \times 10^{-1}$ \\
\hline $\mathrm{M}_{8}$ & 0 & 0 & 0 & 0 & 0 \\
\hline $\mathrm{M}_{9}$ & 0 & 0 & 0 & 0 & 0 \\
\hline $\mathrm{M}_{10}$ & 7 & 10 & 0 & 85 & $8.5 \times 10^{-1}$ \\
\hline
\end{tabular}

Tabel 4.2 Hasil Identifikasi Pada Sampel Margarin

\begin{tabular}{|c|c|c|}
\hline \multirow{2}{*}{$\begin{array}{c}\text { Kode } \\
\text { Sampel }\end{array}$} & \multicolumn{2}{|c|}{ Isolasi dan Identifikasi } \\
\cline { 2 - 3 } & Salmonella sp. & $\begin{array}{c}\text { Staphylococcus } \\
\text { aureus }\end{array}$ \\
\hline$M_{1}$ & Negatif & Negatif \\
\hline$M_{2}$ & Negatif & Negatif \\
\hline$M_{3}$ & Negatif & Negatif \\
\hline$M_{4}$ & Negatif & Negatif \\
\hline$M_{5}$ & Negatif & Negatif \\
\hline$M_{6}$ & Negatif & Negatif \\
\hline$M_{7}$ & Negatif & Negatif \\
\hline$M_{8}$ & Negatif & Negatif \\
\hline$M_{9}$ & Negatif & Negatif \\
\hline$M_{10}$ & Negatif & Negatif \\
\hline
\end{tabular}

Berdasarkan hasil penelitian yang disajikan pada tabel 4.1 dapat disimpulkan bahwa 10 sampel tersebut memenuhi Standart Nasional Indonesia (SNI) tentang batas maksimum cemaran mikroba dalam pangan, khususnya margarin yang batas maksimum cemarannya $1 \times 10^{5}$ koloni/g dikarenakan ALT bertujuan untuk mengetahui kualitas sampel (BSN, 2009).

Sedangkan pemeriksaan identifikasi yang disajikan pada tabel 4.2 dapat disimpulkan bahwa 10 sampel margarin curah bermerk yang di jual di Sukodono juga tidak ditemukan adanya bakteri Salmonella sp. dan Staphylococcus aureus. Dari hasil identifikasi dapat disimpulkan bahwa bahwa margarin layak untuk dikonsumsi masyarakat karena batas maksimum cemaran mikroba pada Salmonella sp. ialah negatif/25g, sedangkan 
pada bakteri Staphylococcus aureus $1 \times 10^{-2}$ koloni/g (BSN, 2009).

\section{Pembahasan}

Margarin merupakan produk berbentuk emulsi, baik semipadat maupun cair yang dibuat dari lemak makan dan atau minyak makan nabati dengan atau tanpa perubahan kimiawi termasuk hidrogenasi, interesterifikasi dan telah melalui proses pemurnian sebagai bahan utama serta mengandung air dan bahan tambahan pangan yang diizinkan (BSN, 2002).

Hasil pemeriksaan hitung jumlah total bakteri serta identifikasi bakteri Salmonella sp. dan Staphylococcus aureus yang telah dilakukan di laboratorium diketahui bahwa 10 sampel margarin curah telah diperiksa memenuhi syarat karena tidak melebihi batas SNI, hal ini disebabkan oleh penerapan higiene dan sanitasi makanan yang baik.

Higiene sanitasi adalah upaya untuk mengendalikan faktor risiko terjadinya kontaminasi terhadap makanan, termasuk bahan tambahan makanan (PerMenKes, 2011).

Margarin sedikitnya mengandung 80\% lemak dari total beratnya. Sisanya (17-18\%) terdiri dari turunan susu skim, air dan protein kedelai cair. Dan ada 1-3\% merupakan garam yang ditambahkan sebagai flavor. Tahap pembuatan margarin yang pertama ialah tahap netralisasi yang merupakan suatu proses pemisahan asam lemak bebas dari minyak atau lemak dengan cara mereaksikan asam lemak bebas dengan basa atau pereaksi lain. Di skala industri banyak menggunakan kaustik soda $(\mathrm{NaOH})$, karena lebih efisien dan murah dengan bahan netralisasi lainnya. Tahap selanjutnya yaitu tahap bleaching (pemucatan), suatu proses pemurnian untuk menghilangkan zat-zat warna yang tidak disukai dalam minyak dengan cara mencampur minyak dengan adsorben seperti bleacing earth (tanah pemucat) dan karbon aktif. Zat warna dalam minyak akan diserap oleh permukaan adsorben dan juga menyerap suspensi koloid (gum dan resin). Pada tahap ketiga merupakan tahap hidrogenasi yang merupakan proses pengolahan minyak atau lemak dengan penambahan hidrogen murni dan ditambahkan serbuk nikel (sebagai katalisator) sehingga mengurangi ketidak jenuhan minyak atau lemak, dan membuat lemak bersifat plastis. Untuk tahap keempat merupakan tahap emulsifikasi pada proses ini bertujuan untuk mengemulsikan minyak dengan cara penambahan emulsifier fase cair dan fase minyak pada sushu $80^{\circ} \mathrm{C}$ dengan tekanan $1 \mathrm{~atm}$ (Govindra, 2015).

\section{Kesimpulan}

Dari 10 sampel margarin curah, tidak ditemukan adanya cemaran Salmonella sp.dan Staphylococcus aureus. 3 dari 10 total jumlah sampel margarin curah yaitu pada sampel dengan kode 6,7 dan 10 didapatkan jumlah total bakteri $6.5 \times 10^{-1} \mathrm{cfu} / \mathrm{g}$ sampel, $2 \times 10^{-1} \mathrm{cfu} / \mathrm{g}$ sampel, $8.5 \times 10^{-1} \mathrm{cfu} / \mathrm{g}$ sampel. 10 sampel margarin tersebut memenuhi persyaratan sebagai bahan tambahan pangan sesuai dengan SNI 01-3541-2002 (BSN, 2002).

\section{Ucapan Terimakasih}

Penulis mengucapkan terimakasih kepada Ibu Evy Ratnasari Ekawati, S.S.i, M.Si selaku pembimbing dan pendamping saat penelitian.

\section{Daftar Pustaka}

Berger, K. G. and Aini, N. (2005) 'Formulation of Zero- trans Acid Shortenings and Margarines and Other Food Fats with Products of the Oil Palm', 82(11), pp. 775-776.

BSN (2002) ‘Sni 01-3541-2002’.

BSN (2009) 'Batas maksimum cemaran mikroba dalam pangan'.

Ekawati, E. R., Pradana, M. S. and Darmanto, W. (2019) 'Lime (Citrus aurantifolia) Peel as Natural Antibacteria for Wound Skin Infection 
Caused by Staphylococcus aureus', International Journal of Pharmaceutical Research, 11(1), pp. 363-366. doi: Research Article https://doi.org/10.31838/ijpr/2019.11.0 1.042 .

Ekawati, E. and Yusmiati, S. N. H. (2018) 'Detection of Salmonella sp., Vibrio sp. and total plate count bacteria on blood cockle ( Anadara granosa)', IOP Conference Series: Earth and Environmental Science, 102, p. 012086. doi: 10.1088/1755-1315/102/1/012086.

Govindra (2015) 'Uraian Proses Pembuatan Margarin'. Available at: http://id.scribd.com/document/2922275 64.

Hasibuan, H. A. (2009) Plastic Fat Berbahan Dasar Minyak Sawit dan Minyak Inti Sawit. Monograf. Medan: Pusat Penelitian Kelapa Sawit.

Hasibuan, H. A. and Hardika, A. P. (2015) 'Formulation and Production of Margarine Using Palm Oil Fractions in Small-Scale Industry and Its Application', J. Agritech, 35(4), pp. 377-386.

Jawetz, Melnick and Adelberg (2017) Mikrobiologi Kedokteran. Edisi 27. Jakarta: Penerbit Buku Kedokteran, EGC.

PerMenKes (2011) 'Higiene Sanitasi Jasaboga'.

Widyastuti and Palupi (2011) Pedoman Mutu Air Minum. Edisi 3. Jakarta: Buku Kedokteran, EGC. 